\title{
Rural Peoples' Perception to Climate Variability/Change in Cross River State-Nigeria
}

\author{
Cyprian A. Egbe, ${ }^{1}$, Margaret A. Yaro, ${ }^{2}$, Asuquo E. Okon, ${ }^{3} \&$ Francis E. Bisong, ${ }^{3}$ \\ ${ }^{1}$ Department of Geography \& Environmental Studies, Alvan Ikoku Federal College of Education, Owerri, Imo \\ State, Nigeria \\ ${ }^{2}$ Department of Urban and Regional Planning, Cross River University of Technology, Calabar, Nigeria \\ ${ }^{3}$ Department of Geography \& Environmental Science, University of Calabar, Calabar, Nigeria \\ Correspondence: Margaret A. Yaro, Department of Urban and Regional Planning, Cross River University of \\ Technology, Calabar, Nigeria. E-mail: mamboline2004@yahoo.com
}

Received: August 13, 2013 Accepted: December 3, 2013 Online Published: February 19, 2014

doi:10.5539/jsd.v7n2p25 URL: http://dx.doi.org/10.5539/jsd.v7n2p25

\begin{abstract}
The rural people have been recognized as knowledge holders on climate variability/change and key actors for developing policies to mitigate and cope with its effects. The study attempts to assess perception level of rural people to Climate change in selected communities in Cross River State, Nigeria. Primary data were collected from 120 rural dwellers in 4 communities. This data centered on knowledge (awareness) level of climate variability/change causes, effects, mitigation and adaptive strategies. The data generated were analyzed using the descriptive statistics. Results showed $71.7 \%$ of the people are aware of climate change. They also indicated that the onset of rains is now delayed while cessation is earlier against the trend in the past. This corroborates the meteorological parameters obtained from Nigeria Meteorological Agency. The Study further indicates that, though there are natural causes, $66.7 \%$ of rural people accepted human activities as major causes of climate change/variability. The results also showed that the effects of climate in rural areas include poor crop yields (56.7\% response); reduced soil fertility $(66.7 \%$ response); increase flood $(56.7 \%)$, poverty and food shortage (50\% response). The sources of peoples' awareness show widespread information from environmental education/sensitization by NGOs and extension workers as well as media which at the moment is lacking and limited to radio talks and jingles. It is recommended that the more awareness should be created on the effect of human activities on climate; also, indigenous knowledge system should complement global modern knowledge systems to enhance climate change mitigation.
\end{abstract}

Keywords: rural people, perception level, climate variability/change, mitigation/adaptation measures, uncertainties

\section{Introduction}

Climate variability/change scenario represents a significant environmental social and economic threat which is now recognized by the majority of the world's governments and scientists as an issue of extreme concern. Climate variability/change is attributed directly or indirectly to human activity and is usually observed over time (Mings, 2008). This phenomenon today is one of the most serious threats to sustainable development both in the urban and rural environment. The anticipated adverse effects or impacts are equally attributable to natural activities which impact on environment and human health, food security, economic activities, natural resource, physical infrastructure and agriculture which is considered the most vulnerable (Lang et al., 2007).

Climate change briefly refers to the long-term significant change in the "average weather" that a given region experience. Climate variability refers to the variation in the mean state and other statistics of climate on all temporal and spatial scales beyond that of individual weather events (Inter governmental Panel on Climate Change (IPCC) 2007, United Nations Frame Work Convention on Climate Change (UNFCCC) 1992).

These events are altered by environmental forces and processes which give high or low, cool or hot or warm temperature.

Recently, issues of climate variability and change have been on the front burner of society's environmental discourse the world over. This is because of the precarious state of the global environment which is now 
possessed by eminent unpredictable weather conditions resulting in climate variability and change. Yet, there may be deficiency in awareness especially in areas where dissemination of information is a problem. This has become critical because climate change will significantly affect production of farmers, livestock keepers, fishers and forest-dependent people, particularly in areas with persistent soil and water scarcity, high exposure to floods, droughts, which increases poverty and hunger (Huq et al., 2003; FAO, 2013). The level of awareness differs by experience and of interest in resource use. In most studies, rural farmers' level of awareness seems to be on increase regarding their experiences in change and length of seasons, incidence of environmental hazards such as flood, droughts, and crop failures, long term shift in wind speed, Change in rainfall intensity and uncertainty of rain etc. (Morghadiya \& Smarden, 2011). These are among the common indicators of climate change well known to rural farmers the world over. However, are people also aware that most human activities contribute to climate change?

Presently, climate models agree that there will be change, and that this change will vary significantly from place to place, but they disagree on the magnitude of that change, and they are also not able to tell us exactly what form that change will take at the local level (Royal Society, 2010 in Levine et al., 2011). The uncertainty on the magnitude of change makes awareness imminent at all level. The present solution to man's survival on the earth's environment sustainably hinge on the option of knowledge (awareness) of climate change and adopting mitigation and adaptation measures as well as best practices. This is because awareness builds response for effective mitigation and adaptation measures as widely recognized as vital components or approaches to reducing climate variability and change (Gbetibouo, 2009).

Various studies have shown that without awareness, mitigation or adaptation measures to climate variability and change will remain a challenge, this will generally be detrimental to the environment as a whole especially agricultural sector, and that it is only through knowledge and awareness that the vulnerability of the entire environment can largely be reduced (Adeoti \& Ajibola, 2008; Gworgwor, 2008; Mendelsohn, 1998; Rosenzweig \& Parry, 1994). Besides, the degree to which an environment is affected by climate change depends on one hand on the level of perception by individuals and the other on mitigation and adaptive capacity to the change phenomenon. Risk perception on the other hand is a subjective evaluation of the probability of hazard occurrence and concern about its consequences which often influence peoples' adaptation and mitigation.

Adaptive capacity in every respect is the ability of system to adjust to the change (climate change including variability and extremes) to moderate or reduce potential damage, take advantage of opportunities or to cope with the consequences of the event (IPCC, 200; Mortimore \& Manvell, 2011). Therefore, the adaptive capacity of any society or system in the environment invariably describes its knowledge of the events, ability to modify or reduce its characteristics or behaviour in order to cope better with the changes in external conditions.

Studies have also shown that vulnerability studies have shifted the focus of research from estimating impacts of climate change to the understanding of adverse change mitigation or adaptation and decision making process (Ambo, 2011; Smith et al., 1996; Maddison, 2006; Belliveau et al., 2006 in Gbetibouo, 2009). These studies have raised questions regarding how people perceive climate variability and change. They have also identified those climate properties which are of most importance to the environment and agriculture in their decision making and have suggested the types of adaptive responses that can be anticipated.

In most rural areas, one important issue in adaptation or mitigation measures especially in the environment or agriculture is the manner in which people update their expectations of climate change in response to unusual weather patterns. According to Maddison (2006) in Gbetibuou (2009), this update lags behind actual climate change. Citing an instance, a farmer may perceive severe hot weather or temperature and rationally attribute them to random variation in a stationary climate. To him this idea can be faulted from the point of view that, farmers in most cases, engage in simple updating of their prior beliefs according to a standard formula. These views imply that, the process of updating will be slow and cannot expect decades of information to be disseminated in a short time. Another issue is pointed out by Ambo (2011) that, adaptation level is determined by how perception of climate variability/change is translated into agriculture and sustainable decisions. Maddison (2006) in Gbetibuou (2009) concluded that if farmers learn slowly or gradually about the change in climate, that means that they will also learn gradually about the best adaptation or mitigation measures or techniques and options that may be available. To him, the people learn the best adaptation measures by doing, learning to cope and learning from instructions.

One barrier to the recognition of man-made causes of climate change is the natural variability of change. Thus there is the need for the public to be aware of the consequences of human causes of Climate change to the environment. Until the public is able to perceive this and if effective actions are not taken to slow the trend of 
change, mere recognition to change will remain critical. In most recent times, the high vulnerability of African and Nigerian to various manifestations of climate variability/change has been confirmed in reports of the IPCC and other publications. According to Olsen (2006), African countries are prone to greater impacts of this variability/change in climate partly because of the lack of awareness and adaptive capacity. Yet, Africa's total contribution to emissions of greenhouse gases which cause the change is less than $7 \%$ of the world's greenhouse emissions (Olsen, 2006).

In the context of Nigeria as is in Swaziland, according to Manyatsi et al. (2010), the most susceptible sectors of human life which are sensitive to climate variability and change and hence highly at risk are water resources, agriculture, tourism, natural resources and biodiversity, health and food supply and security. Abnormal changes in temperature and rainfall and the increasing frequency and intensity of drought and floods in most parts of the states in Nigeria such as Benue, Cross River, Imo, Anambra, Kogi, Sokoto, Kaduna Rivers, Bayelsa and so on have brought long-term implications for the viability and productivity of the world agro-systems especially among rural communities. These occurrences are linked to nature and man-made as prime agents. Reports have shown that, among the reasons behind man-made occurrences are levels of perception as well as traditional belief systems (Adebayo \& Oruonye, 2012; Aderinwale \& Amosun, 2012; Manyatsi et al., 2010).

In Nigeria especially in the rural areas, tradition and culture often determines and influence their belief systems. These belief systems determine their levels of perception and influences their interactions with the environment especially farmers. Thus, scenarios of climate variability and change are often times perceived by these rural people as natural occurring events which may not have any adverse effects on the environment and the future. One major reason for this is lack of awareness or adequate and prompt information on contemporary climate trends as well as affordable and feasible adaptive or mitigation measures or strategies.

Despite the nature of their perception, the rural people are also seen as valuable actors for developing and implementing mitigation policies as well as cope with the climate change effects. Their indigenous knowledge has been recognized as a powerful and important source of climate change knowledge and for formulating mitigation and adaptation strategies. Ambo (2011), Natural Science (2012) and Inter Indigenous People Forum on Climate Change (IIPFCC) 2009 in Adebayo and Oruonye (2012) also observed that traditional innovations and adaptation practices usually embody local adaptive management strategies to the changing environment and complements scientific research, observations and monitoring.

Besides, most rural communities possess traditional and local knowledge that may help them adapt better to the impacts of climate variability/change. For example, some communities use traditional knowledge to record observations of climate variability/ change and their impacts on the environment even before the change become threatening. Because of their close relationship with the land and dependence on natural resource exploitation for livelihood, they can also observe and note the changes in climate conditions (United Nations Education Scientific and Cultural Organisation (UNESCO), 2012). This study was thus driven by the desire to assess rural peoples' perception of climate variability/change in Cross River State in order to ascertain indicators of climate variability that propel their understanding as well as coping strategies, contribute to the data base among others, policy formulation of successful and effective mitigation and adaptation initiatives to reduce the existing negative impacts caused by climate phenomena.

\subsection{The Problem}

Climate variability/change is the major and perhaps the most critical of all environmental challenges which confronts societies in the present century. Crucial information pertaining to perception of climate variability/change by people especially in the rural areas is lacking. Successful implementation of mitigation and or adaptation strategies of any kind has strong bearing on the changes in behaviour of the people whose individual choices may have huge collective impacts at global scale. Observation show that, there is however, limited in-depth understanding of the perception of the public (people) to climate change and variability especially among rural people/communities.

The knowledge and perceptions of communities and the people about climate variability/change influence the way they respond to mitigation and adaptation initiatives and climate policies. Notwithstanding, there is also a growing awareness that scientific knowledge on the causes of climate variability/change is becoming inadequate in solving climate variability and change phenomena. Therefore, indigenous or local people understanding need be involved as direct stakeholders in the rural environment who also contribute to climate variability/change. This study assessed the rural peoples' perception of climate variability/change and effective mitigation and adaptation methods in the study area. 


\subsection{Study Area}

The study was undertaken in four (4) rural communities in Etung and Boki Local Government Areas (L.G.As) of Cross River State respectively. These are Bendeghe-Ekiem and Abia Communities in Etung and Abu and Kanyang communities in Boki L.G.As'. The communities were selected to represent the major agricultural ecological zone both at the local government area and the entire southern and central ecological zones which is predominantly tropical rainforest vegetation in nature. This ecological zone stretches from the Bakassi and Akamkpa in the southern part of the state into Yakurr, Obubra, Ikom, Etung to Boki L.G.As in the central zone.

Rainfall patterns are almost universal in these areas averaging over $1500 \mathrm{~mm}$ per annum and farmers utilize the forest environment for the exploitation of timber and non-timber products as well as farming. There are also plantation farms which are owned by both private farmers as well as government. Crops cultivated range between cash crops like cocoa, rubber, oil palm and food crops such as yams, plantains, banana, cassava, vegetables and so on. They also do hunting for bush meat, fishing and other traditional occupations.

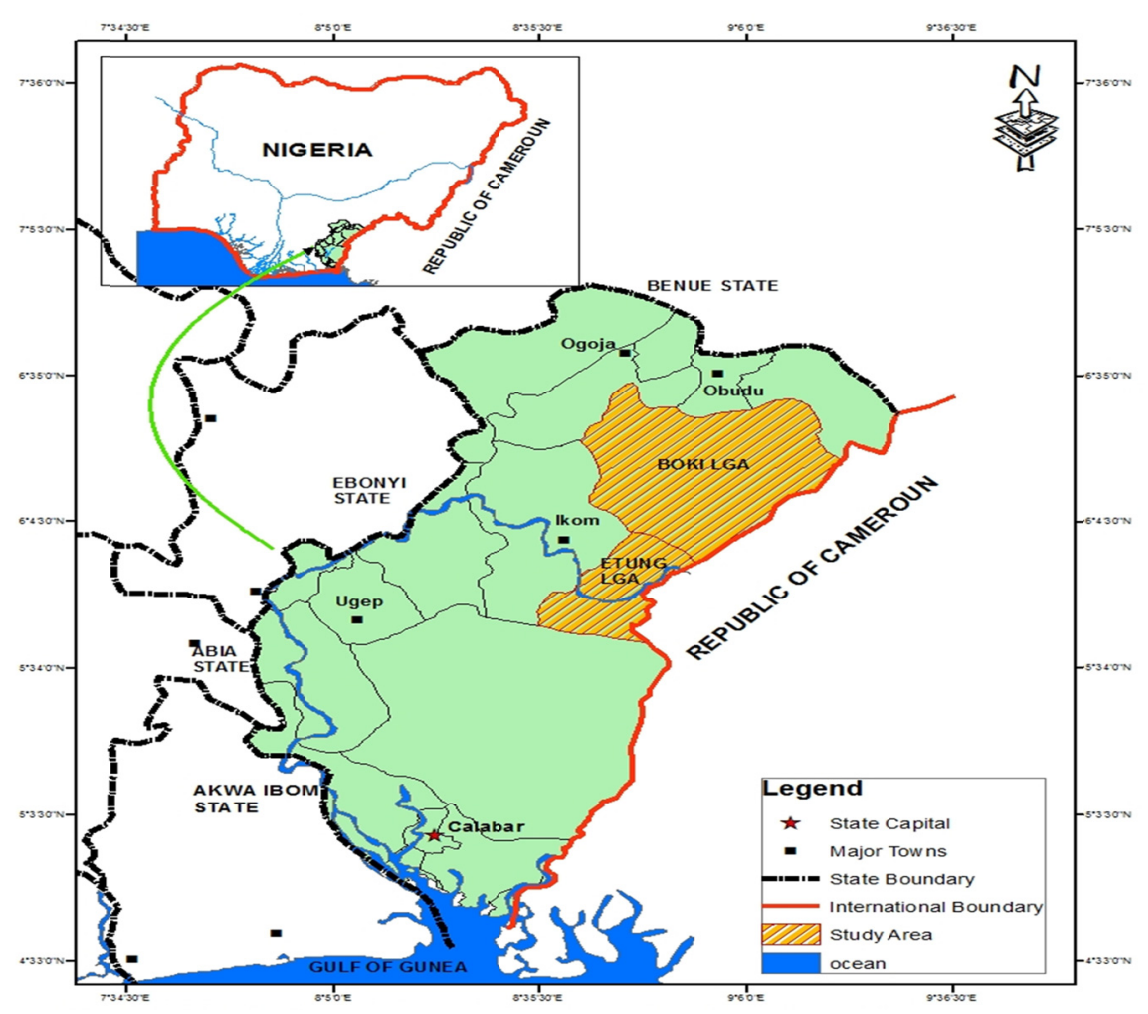

\section{Methodology}

The Data collected were sourced through interviews and the use of check list. Also the questionnaire was utilized as a valuable instrument for the data needed. Interview in the form of questionnaire were administered to a total of 120 farmers and other resource members from the four communities (representing five percent of the total farming population), 30 from each of the communities of study. Respondents were given the opportunity of multiple choices as option. The questions were generated from the interaction with the local people during reconnaissance survey in the area. Some useful information was elicited from the people on the indicators of climate change in their domain and their experiences as well as adaptation mechanism in operation. A checklist was also adopted to obtain information which was not contained in the questionnaire list. A simple random method was then employed in the selection of respondents and distribution of questionnaire. The information that was sought included signs of climate variability/change as perceived by the people in rural communities, awareness of the term climate variability/change, perceived causes, effects, attitude, as well as traditional livelihood/coping strategies adopted (mitigation and adoption strategies). Focused group discussion was conducted through a checklist in each of the communities to elicit information for the different livelihood 
strategies and coping mechanisms practiced by the people. The questions were necessary to ascertain the perception of rural people to climate issues in relation to their livelihoods.

\section{Results}

Table 1 explains the level of awareness of climate change by the local people. Awareness to this end is ensuring response and adaptation to climate variability. This was carried out in collaboration with the people. The nature of awareness were tackled by the different options to detect variability the result show that majority of the respondents in the communities sampled are already aware of climate variability and change. Precisely about 40-86 respondent representing about 33.3-71.7\% from the multiple response options strongly admitted to observed signs of climate change as longer dry seasons, low, and warmer temperature. Majority of respondents also perceived the observed changes in climate to include strong winds, severe flooding, delayed onset of rains/early cessation and stormy weather. However, respondents have not notice drying of streams and rivers in the area.

Table 1. Perception of climatic variability/change (awareness)

\begin{tabular}{clcccccc}
\hline & & \multicolumn{5}{c}{ Responses } \\
\cline { 2 - 7 } S/N & Perception/observed change & Yes & $\%$ & No & $\%$ & No experience \\
\hline 1 & There is climate change in recent years & 86 & 71.7 & 16 & 13.3 & 18 & 15.0 \\
2 & Dry seasons are longer & 77 & 64.2 & 37 & 30.8 & 6 & 5.0 \\
3 & There is low rainfall & 51 & 42.5 & 44 & 36.7 & 25 & 20.8 \\
4 & Temperatures are warmer & 75 & 62.5 & 26 & 21.7 & 19 & 15.8 \\
5 & Strong winds in recent times & 80 & 66.7 & 20 & 16.7 & 20 & 16.7 \\
6 & Severe flooding & 74 & 61.7 & 26 & 21.7 & 20 & 16.7 \\
7 & Drying up of streams / rivers & 40 & 33.3 & 70 & 58.3 & 10 & 8.3 \\
8 & Delayed onset of rains / early cessation/ stormy weather & 62 & 51.7 & 42 & 35.0 & 16 & 13.3 \\
\hline
\end{tabular}

Source: Researchers' fieldwork survey (2012).

Table 2 shows the perceived causes of climate variability and change in the study area. These causes were listed to include natural causes as well as human. A higher percentage of $33.3-67.0 \%$ of the respondents listed natural and human as the cause. $17 \%, 13 \%$ and $8 \%$ of the respondents listed the causes as traditional, disobedient of the Gods and biblical manifestation of the end time. While $50 \%$ of the respondents perceived that technological innovations is the cause, a negligible $4.7 \%$ of the respondents perceived supernatural power to be the cause of climate variability and change. Majority of respondents opted for human as the main causes of climate change. Linking this data to the variations in Temperature and rainfall from the Nigeria Meteorological Agency (NMA, 2011), there is corroboration between the perception of the people and the meteorological records (Figure 1 and $2)$. 


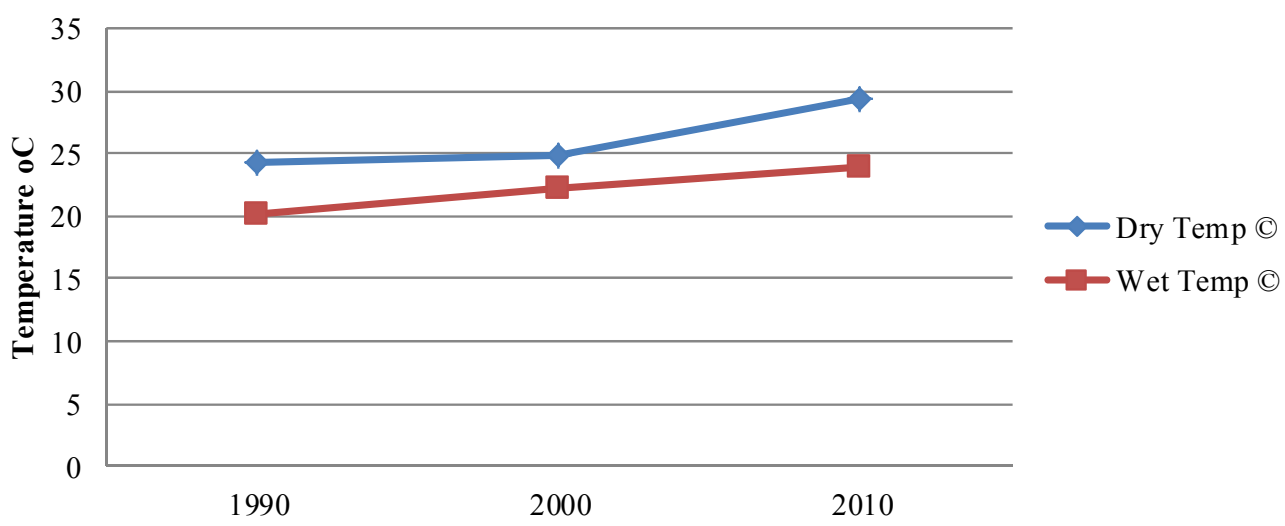

Figure 1 . Temperature variation in the study area

Source: Extract from Nigeria Meteorological Station (2011).

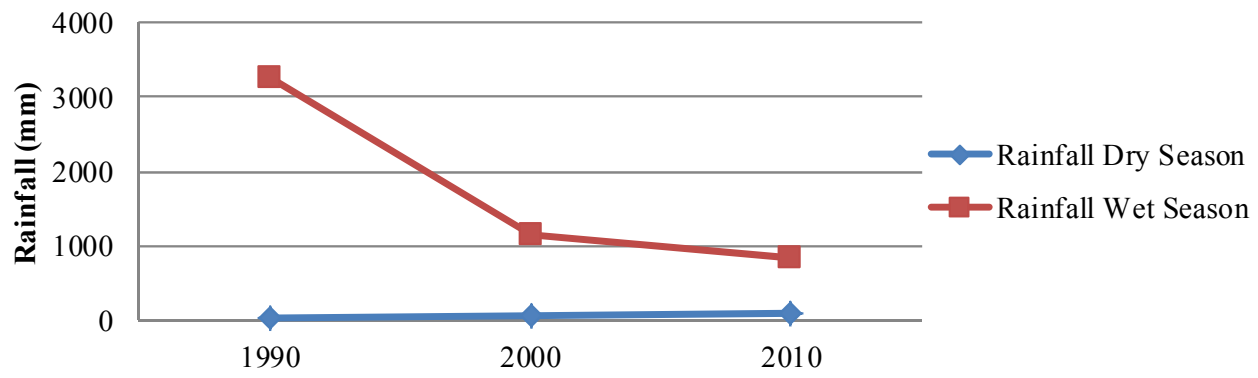

Figure 2. Variation in Rainfall within the study area

Source: Extract from Nigeria Meteorological Station (2011).

Table 2. Perceived causes of climate variability \& change

\begin{tabular}{llcccccc}
\hline \multirow{2}{*}{ S/N } & \multirow{2}{*}{ Perceived Causes } & \multicolumn{7}{c}{ Responses } \\
\cline { 3 - 8 } & & Yes & $\%$ & N0 & $\%$ & No experience & $\%$ \\
\hline 1 & Natural causes & 40 & 33.3 & 50 & 41.7 & 30 & 25.0 \\
2 & Human causes & 80 & 66.7 & 25 & 20.8 & 15 & 12.5 \\
3 & Traditional neglect & 20 & 16.7 & 79 & 65.8 & 21 & 17.5 \\
4 & People disobeying the gods & 15 & 12.5 & 83 & 69.2 & 22 & 18.3 \\
5 & Biblical manifestation & 10 & 8.3 & 75 & 62.5 & 35 & 29.2 \\
6 & Technology & 60 & 50.0 & 37 & 30.8 & 23 & 19.2 \\
7 & Supernatural powers & 5 & 4.2 & 85 & 70.8 & 30 & 25.0 \\
\hline
\end{tabular}

Source: Researchers' fieldwork survey (2012).

In Table 3 below, the observed effects by respondents include poor crop yield (56.7\% of the respondents), increased disease infestation (only 8.3\%), reduced soil fertility (66.7\%), reduced vegetation and pasture (33.3\%), increased flooding and poverty (56.6\% and $50.6 \%$ respectively), leading to insufficient food supply. The perceived effects observed were mostly personal views and family centered. Effects such as poor crop yield, increased disease infestation, reduced soil fertility, reduced vegetation/pastures and increased flooding, were general and attributed to human activities. 
Table 3. Perceived effects of climate variability and change

\begin{tabular}{clcccccc}
\hline S/N & Perceived Effects & YES & $\%$ & NO & $\%$ & No Experience & $\%$ \\
\hline 1 & Poor crop yield in recent times & 68 & 56.7 & 32 & 26.7 & 20 & 16.7 \\
2 & Increased disease infestation & 10 & 8.3 & 70 & 58.3 & 40 & 33.3 \\
3 & Reduced soil fertility & 80 & 66.7 & 25 & 20.8 & 15 & 12.5 \\
4 & Reduced vegetation/pastures & 40 & 33.3 & 45 & 37.5 & 35 & 29.2 \\
5 & Increased flooding & 68 & 56.7 & 29 & 24.2 & 23 & 19.2 \\
6 & Poverty & 60 & 50.0 & 36 & 30.0 & 24 & 20.0 \\
7 & Insufficient food supply & 60 & 50.0 & 51 & 42.5 & 9 & 7.5 \\
\hline
\end{tabular}

Source: Researchers' fieldwork survey (2012).

In the result of Table $4,70.8 \%$ of the respondents admitted that climate variability/change is real and a global issue which requires urgent attention. Another $33.3 \%$ perceived it as a natural event which nothing can be done to control it. While $25 \%$ of the respondents suggested that the gods should be appeased, $33.3 \%$ opined that only scientists should be concerned with the issue and $65 \%$ suggested that everyone play a role in combating climate change since they are all part of the world.

Table 4. Attitude of people to climate variability/change in the study area

\begin{tabular}{|c|c|c|c|c|c|c|c|}
\hline $\mathrm{S} / \mathrm{N}$ & Observed Attitude & Yes & $\%$ & No & $\%$ & $\begin{array}{c}\text { No } \\
\text { experience }\end{array}$ & $\%$ \\
\hline 1 & Natural events and no change can be done & 40 & 33.3 & 68 & 56.7 & 12 & 10.0 \\
\hline 2 & The gods should be appeased & 30 & 25.0 & 80 & 66.7 & 10 & 8.3 \\
\hline 3 & $\begin{array}{l}\text { Change is real and a global issue that requires } \\
\text { urgent attention }\end{array}$ & 85 & 70.8 & 20 & 16.7 & 15 & 12.5 \\
\hline 4 & Only scientist should be concerned with the issue & 40 & 33.3 & 69 & 57.5 & 11 & 9.2 \\
\hline 5 & $\begin{array}{l}\text { Everyone on earth has a part to play in combating } \\
\text { the adverse change }\end{array}$ & 78 & 65.0 & 36 & 30.0 & 6 & 5.0 \\
\hline
\end{tabular}

Source: Researchers' fieldwork survey (2012).

Table 5. Sources of information about climate variability and change

\begin{tabular}{|c|c|c|c|c|c|c|c|}
\hline $\mathrm{S} / \mathrm{N}$ & Source of Information & Yes & $\%$ & No & $\%$ & $\begin{array}{c}\text { No } \\
\text { experience }\end{array}$ & $\%$ \\
\hline 1 & Natural experience & 10 & 8.3 & 70 & 58.3 & 40 & 33.3 \\
\hline 2 & Media (Radio/Television) & 57 & 47.5 & 48 & 40.0 & 15 & 12.5 \\
\hline 3 & Workshops/conferences & 46 & 38.3 & 56 & 46.7 & 18 & 15.0 \\
\hline 4 & Extension Agents & 60 & 50.0 & 39 & 32.5 & 21 & 17.5 \\
\hline 5 & $\begin{array}{l}\text { Education/sensitization (NGOs, books, } \\
\text { Newspaper, and school) }\end{array}$ & 80 & 66.7 & 22 & 18.3 & 18 & 15.0 \\
\hline 6 & Hear-say from people in the area. & 15 & 12.5 & 65 & 54.2 & 40 & 33.3 \\
\hline
\end{tabular}

Source: Researchers' fieldwork survey (2012).

In Table 5 below, most respondents claimed to have their information from all sources listed. However, $47.5 \%$ of the total respondents claimed they get their information from the media. This implies that the press should be more active in disseminating information to this level of people in the society. Also, 38.3\% of the respondents claimed to get information through workshops and conferences, $50 \%$ claimed to have information from 
extension workers, $66.7 \%$ from education from NGOs and schools and only $12.5 \%$ agreed to have their information from others around but do not really understand what climate variability/change is all about.

The Strategies to cope (mitigation/adaptation) with climate variability/change effect is presented in Table 6 . The traditional livelihood strategies adopted to cope with climate change incidence were general in all communities sampled. These include reduction in timber exploitation, reduction in non-timber forest products exploitation and bush burning. In alternative, they depend on occupations like bike transportation, food vendoring and establishment of boreholes as source of domestic and drinking water. They abide by traditional customs like shorter shifts in cultivation; they plant trees, adopt homestead farming/permanent farmland and also pray for God's intervention. The response shows that adherence to traditional customs (63.3\% response), tree planting (60\% response), homestead farming (60\% response) and alternative livelihood (50\% response) are the preferred options for mitigation of climate variability. However, many people do not see reduction in bush burning as a viable mitigation action. Only $25.0 \%$ of the people accepted it.

Table 6. Mitigation/Adaptation strategies to cope with climate variability/change effects

\begin{tabular}{llcccccc}
\hline S/N & Strategies & \multicolumn{5}{c}{ Responses } \\
& & $\begin{array}{c}\text { No. of } \\
\text { Responses }\end{array}$ & $\%$ & No & $\%$ & No & $\%$ \\
& & & & & \\
experience & \\
\hline 1 & Reduced use of Timber/ fuel wood & 40 & 33.3 & 49 & 40.8 & 31 & 25.8 \\
2 & $\begin{array}{l}\text { Reduction in the use of Non Timber } \\
\text { forest product (NTFP) }\end{array}$ & 40 & 33.3 & 46 & 38.3 & 34 & 28.3 \\
3 & Reduced bush burning & 30 & 25.0 & 36 & 30.0 & 54 & 45.0 \\
4 & Adopt alternative occupations & 50 & 41.7 & 39 & 32.5 & 31 & 25.8 \\
5 & Abide by traditional customs & 76 & 63.3 & 23 & 19.2 & 21 & 17.5 \\
6 & Plant trees & 60 & 50.0 & 31 & 25.8 & 29 & 24.2 \\
7 & Adopt homestead farming/permanent & 60 & 50.0 & 28 & 23.3 & 32 & 26.7 \\
& farmlands & & & & & & \\
8 & Prayers for God's intervention & 5 & 4.2 & 59 & 49.2 & 56 & 46.7 \\
\hline
\end{tabular}

Source: Researchers' fieldwork survey (2012).

The result of meteorological parameters in Table 7 and 8 show variation in temperature, rainfall, relative humidity and months of dry and wet season. Between 1990 and 2000 in the dry season, average temperature change was $0.7{ }^{\circ} \mathrm{C}$ and between 2000 and 2010 the change increase to $4.4{ }^{\circ} \mathrm{C}$, that of rainfall rather show increase; while the months of wet and dry season was at equilibrium. This is in line with the perception of the people in Table 1.

Table 7. In-situ Climatic parameters recorded in the Area in may, 2013

\begin{tabular}{ccccc}
\hline Location & $\begin{array}{c}\text { Wind } \\
\text { Speed } \\
(\mathrm{m} / \mathrm{s})\end{array}$ & $\begin{array}{c}\text { Relative } \\
\text { Humidity } \\
(\%)\end{array}$ & $\begin{array}{c}\text { Temp } \\
\left({ }^{\circ} \mathrm{C}\right)\end{array}$ & Rainfall $(\mathrm{mm})$ \\
\hline Boki 1 & 0.3 & 89.4 & 20.2 & 2521 \\
Boki 2 & 0.2 & 84.2 & 23.6 & 2663 \\
Etung 1 & 1.3 & 89.8 & 20.9 & 3123 \\
Etung 2 & 1.4 & 88.3 & 20.2 & 2312 \\
\hline
\end{tabular}


Table 8. Selected Meteorological parameters of the study area

\begin{tabular}{|c|c|c|c|c|c|c|c|c|}
\hline \multirow[t]{2}{*}{ Period } & $\begin{array}{l}\text { Relative } \\
\text { Humidity }\end{array}$ & $\begin{array}{l}\text { average } \\
\text { Temp }\end{array}$ & \multirow{2}{*}{$\begin{array}{l}\text { Average } \\
\text { Rainfall } \\
\text { (mm) }\end{array}$} & \multirow{2}{*}{$\begin{array}{l}\text { No. of } \\
\text { dry } \\
\text { months }\end{array}$} & $\begin{array}{l}\text { Relative } \\
\text { Humidity }\end{array}$ & $\begin{array}{l}\text { Average } \\
\text { Temp }\end{array}$ & $\begin{array}{l}\text { Rainfall } \\
\text { (mm) }\end{array}$ & $\begin{array}{l}\text { No. of } \\
\text { wet } \\
\text { Months }\end{array}$ \\
\hline & $(\%)$ & $\left({ }^{\circ} \mathrm{C}\right)$ & & & $(\%)$ & $\left({ }^{\circ} \mathrm{C}\right)$ & & \\
\hline & \multicolumn{4}{|c|}{ Dry Season } & \multicolumn{4}{|l|}{ Wet Season } \\
\hline 1990 & 83.4 & 24.2 & 30.4 & 4 & 94.4 & 20.2 & 3253 & 8 \\
\hline 2000 & 87.2 & 24.9 & 51.3 & 5 & 92.6 & 22.3 & 1161 & 7 \\
\hline 2010 & 81.8 & 29.3 & 86.2 & 6 & 91.7 & 23.9 & 842.5 & 6 \\
\hline
\end{tabular}

Source: Extract from Nigeria Meteorological Station (2011).

\subsection{Discussion of Findings}

Investigation show that majority of community members expressed awareness of climate variability and change through perceived longer dry seasons, low rainfall, increased/warmer temperatures and so on in recent times. The meteorological parameters also prove the point of climate variability. Globally, the summary of various survey shows that at least 90 percent of the people are now aware of climate change and out of this number, 30 percent are aware that the effect of climate change has affected their livelihoods (Menioux, 2012). The people are aware of climate change reality though with discerning views on the causes of climate change due to traditional believes such as supernatural powers and so on as causes which trigger climate variability /change. Response on indicators of climate variability invariably confirms the awareness by the people on the changing climate. Researches in many areas on perception and awareness of climate variability indicate that a fair number of people are informed on the changing pattern of the weather system. However, it is often argued that perception is subjective mostly based on experience especially as it's relates to livelihoods. Farmers for instance may view climate change in relation to changing planting seasons. Yet there is a point of consensus which is commonly changing in various weather conditions and length of seasons. In western India for instance, similar study revealed that only 33 percent of people are aware of climate change (Moghariya \& Smarden, 2011). Most of those who are aware of climate variability are educated elite and their basis for climate change is increase in temperature. The practical experience of the people is based on room temperature. Awareness undoubtedly builds response and cooperation. In Nigeria Ufuoku (2011) and Ekong (2003), in their different studies, share awareness rate as high as $80 \%$ which is linked to length of seasons.

Moreover, awareness on the root causes of climate variability on the part of the people is also an indication on the knowledge of climate variability/change. Some rural people do not see anything wrong with bush burning, because it is the easiest way for land preparation for farming. This shows that awareness is seriously needed in this area. The responses were in support of human known causes such as change in technology. In confirmation, findings from Mozambique, Uganda and Ethiopia suggest that people have to cope with sudden shocks of rain and crop failures, hence see climate change as a complex problem that has exacerbated conditions of the people (Levine, Ludi, \& Jones, 2011).

On the perceived effects of climate variability and change, the observed effects were poor crop yield, increased disease infestation, reduced soil fertility, reduced vegetation cover and pastures, increased flooding, poverty and insufficient food supply. Increased flooding, strong winds and stormy weather and loss of vegetation cover were generally perceived views by the people in all the communities sampled. This perceived view corroborates with the study by Manyatsi et al. of 2010 in Swaziland. As suggested by levine, ludi and jones (2011), in order to understand the impact of climate change at local levels, it is important to recognize the interactions between climate change and wider development pressures. Climate change needs to be as part of wider development interventions.

On the people's attitudes, $71.7 \%$ believe that climate variability/change is real but is still a global issue that requires attention. Others feel that the changes are merely natural from creation and are a normal situation and nothing can be done to control the change while some believe that only the gods can change the trend when appeased with prayers. On their source of information and awareness, 40-80\% of members in all the communities sampled presented differing views on their sources of information. While some claimed their sources of information from the media, others claimed to have information from workshops/conferences, extension agents and books. Quite a negligible percentage claimed to be informed through hear-say from 
members in the communities. Response to climate change is usually a problem, for instance in Hungary as noted by Zemankovics (2012) a large number of people were aware of climate change in a national survey carried out in the country where only 33 percent of the people regard climate change as a series problem. Change of attitude will only be effective if climate change is regarded as a serious problem.

Notwithstanding the above claims and deduction, the communities sampled expressed some livelihood coping strategies which they adopt to adapt/mitigate the incidences of climate variability/change in their areas. Some of the strategies/coping mechanisms are general in all sampled communities. These include, reduction in timber and non - timber product exploitation, reduction in bush burning, engaging in alternative occupations like bike transportation, food vendoring and establishment of boreholes as sources of drinking water. Others are adoption of shorter fallow periods, home-stead farming, afforestation efforts, reduced destruction of available watershed and dependence on forest resources and of course prayers to God for intervention. It is important to note that some of these coping strategies are not very feasible and practicable since they require huge finances like the case of alternative occupations as regards establishment of boreholes in rural societies with subsistence economy except supported externally.

Adaptation generally is primarily tailored towards agricultural productions principally through irrigation and planting crop resistant species, most local farmers are aware that the stress on their local environment and livelihoods has increased and low capacity for adaptation is a serious issue (Jones et al., 2011). The provisions made by governments and donors are most times discriminatory and fails to reach the locals. According to Pettengell (2010), poverty, more than any other factor, determines vulnerability to climate change and limits adaptive capacity. It is pertinent to strengthen adaptation of poor farmers to increase their productivity. Ufuoku (2011) corroborate this fact adaptation to climate change requires farmers to realize that the climate has changed and they must be assisted to identify useful adaptation strategies and implement them. There have been various suggestions on intervention to boost adaptive and mitigative capacity of local people. Most times such adaptive mechanism is top-down and exclusive of local peoples' ideas. This fails to address the plight of the people. Information to local people increase response and readiness towards adaptation.

Enhancing indigenous knowledge system is ideal adaptation and mitigation mechanism for climate change (Aganietal, 2013). Integrating indigenous knowledge system into climate change policies can lead to an effective capacity building and adaptive strategies that are cost effective.

Local farmers in sub-Saharan Africa have long been known to adapt and mitigate the effect of climate variability through system such as shifting cultivation, mulching etc. (Schafer, 1989; Osunada, 1994; Stainback et al., 2002; Ajani et al., 2013; Griggs et al., 2013) in Australia. In Indonesia, Motimore and Manvell (2006) opines that increasing local capacity to adapt remains an urgent strategy (Pettengell, 2010; PROLINNOVA, 2012), access to information alone may not change behaviour (Stedman et al., 2012). Significant knowledge gaps need to be addressed, including up scaling of local innovations, increasing awareness on the contribution of bush burning to greenhouse gas emission and the consequences on global climate.

\subsection{Recommendations}

- Awareness/Education on the issues of climate change still needs to be created to expand the level of awareness.

- We cannot adapt to what we don't know because Successful adaptation requires information and understanding of future change, information on climate change should be made available to farmers and other natural resource users to create more awareness and the knowledge on further effects of some human activities (such as bush burning) that contribute to climate change.

- Encourage rural people on alternative occupations and sources of income.

- Land use planning should be part of any interventions programme on climate change as land use change constitute the greatest driver of deforestation.

- Capacity building programme is vital to strengthen climate change adaptation especially in rural areas.

- Participatory adaptation strategy that involves local farmers in decision making and planning will ensure cooperation of local people in climate change adaptation.

- Indigenous knowledge system should complement global modern knowledge systems to enhance climate change mitigation.

- Climate change and adaptive mechanism should be integrative including all other sectors of the economy in the course of planning. 


\subsection{Conclusion}

This study assessed the perception level of rural people to climate variability/change in four communities in the central senatorial zone of Cross River State. The communities were selected from two L.G.As' of Etung and Boki with the back ground of their vegetation characteristics, occupational homogeneity, and cultural and traditional lifestyles and sources of livelihood.

Rural people to a large extent are aware of the dynamics of their local climate; they are aware of climate variability/change issues and have strategies/coping mechanisms. The traditional knowledge practices have been adopted by the people in adapting to climate change impacts among farmers in area. However, some practices such as bush burning which lessen labour in land preparation for farming is seen as not causing climate change. This generates concern for behaviour change and perception in this regard. Notwithstanding, there is the need to synergize local and modern mitigation measures. Moreover, People (individually or collectively) to be responsible as part of the effort to reduce the trend through a review of our life styles. This change will only require a systematic and lasting effort through education and awareness of the people as education here seems the safest way to achieve the desired success. This is done not only by giving the people information, but ensuring that education (awareness) is mobilized to the grass root to re-orient the society towards best/sustainable practices through attitudinal change.

\section{References}

Adebayo, A., \& Oruonye, E. D. (2012). An Investigation of Local Farmers Assessment of Climate Change in N/Taraba State Nigeria. In Conference Proceeding of Nmets. 2012 on Climate Change and variability: Saving Our Tomorrow Today. University of Benin.

Adeoti, J. O., \& Ajibola, L. A. (2008). Role of Government in Climate Change Adaptation in Nigeria. In T. Akande \& A. Kumuji (Eds.), Challenges of Climate Change for Nigeria.

Aderinwale, A. O., \& Amosun, P. A. (2012). Secondary School Students Knowledge of and Attitude to Climate Change Issues in Ibadan in Conference Proceedings of Nmets 2012 Climate Change and Variability: Saving Our Tomorrow Today University of Benin, Benin city. Edo State.

Ajani, E. N., Mgbenka, R. N., \& Okeke, M. N. (2013). Use of Indigenous Knowledge as a Strategy for Climate Change Adaptation among Farmers in sub-Saharan Africa: Implications for Policy. Asian Journal of Agricultural Extension, Economics \& Sociology, 2(1), 23-40.

Ambo, M. E. (2011). Environmental Change and Urban Agriculture: Implications for Food Security in Calabar Nigeria. Unpublished PhD Thesis, Department of Geography and Regional Planning, University of CalabarNigeria.

Fourth Assessment Report. Retrieved from http//www.ipcc.ch/spm6avro7.pdf

Gbetibouo, G. A. (2009). Understanding Farmers' Perception and Adaptations to climate Change and Variability: The Case of the Limpopo Basin, South Africa. International Food Policy Research Institute (IFRI) Discussion Paper 00849, February 2009. Environment and Production Technology Division, IFPRI.

Griggs, D. Joachim, L., \& Kestin, T. (2013). National Workshop on Indigenous Knowledge for Climate Change Adaptation. Echuca Workshop Report. Australia: Monash Sustainability Institute

Gworgwor, N. A. (2008). Climate Change and Sustainable Rural Livelihood in the Sudano-Saliehan Zone of Nigeria. In T. Akande \& A. Kumuji (Eds), Challenges of Climate Change for Nigeria.

IIPFCC. (2009). IIPFCC Policy Paper on Climate Change in Adebayo \& Oruonye 2012. An Investigation of Local Farmers Assessment of Climate Change in N/Taraba State Nigeria.

IPCC. (2007). Climate Change Impacts, Adaptation and Vulnerability. IPCCWGH.

Láng, I., Csete, L., \& Jolánkai, M. (2007). The global climate change: impacts and responses in Hungary-The Report of VA HAVA project. (in Hungarian) Szaktudás Kiadó Ház, 2007.

Levine, S., Ludi, E., \& Jones L. (2011). Rethinking Support for Adaptive Capacity to Climate Change. UK: Overseas Development Institute (ODI).

Lovell, R., \& O'Brien, L. (2009). Wood you believe it? Children and young people's perceptions of climate change and the role of trees, woods and forests. Forest Research. Retrieved from www.forestry.gov.uk/fr/INFD-7UCASC 
Mendelsohn, R., \& Neumann, J. (1999). The Impacts of Climate Change on the U.S Economy. Cambridge, Cambridge University Press. http://dx.doi.org/10.1017/CBO9780511573149

Ménioux, J., \& Zumsteeg, S. (2012). Individual perceptions of climate risks: SURVEY AXA/IPSOS.

Mings, L. (2008). Determination of Knowledge, Attitudes and Practices on Climate Change Issue. Environmental Tourism Consulting.

Moghariya, R., \& Smardon, R. S. (2011). Farmers' Perception of Risk, Impacts and Adaptation to Climate Change. Perspectives from Western India Dinesh: College of Environmental Science and Forestry.

Mortimore, M., \& Manvell. (2006). Climate change: enhancing adaptive capacity. UK: Department for International Development (DFID).

Natural Sciences. (2012). Turning Tables on Climate Changes: Indigenous Assessment of Impacts and Adaptation. Retrieved from http://www.unesco.org/new/en/natural-sciences

Ofuoku, A. U. (2011). Rural Farmers' Perception of Climate Change in Central Agricultural Zone of Delta State, Nigeria. Indonesian Journal of Agricultural Science, 12(2), 63-69.

Olsen, K. H. (2006). National Ownership in the Implementation of Global Climate Policy in Uganda. Clim Policy. http://dx.doi.org/10.1080/14693062.2006.9685581

Oreskes, N. (2004). Beyond Ivory Tower: The Scientific Concensus on Climate Change Science. Retrieved from http/www.science mag.org

Pettengell, C. (2010). Climate Change Adaptation: Enabling people living in poverty to adapt. UK: OXFAM.

Rosenzweig, C. R., \& Parry, M. L. (1994). Potential impact of climate change on world food supply. Nature, 367, 133-138. http://dx.doi.org/10.1038/367133a0

Smith, J. B., Nasr. J., \& Ratta, A. (1996b). Urban Agriculture. Food, Jobs and Sustainable cities. Publication Series for Habitat II, NewYork United Nations Development Program.

Stedman, R. C., Ross, R. M., Allred, S. B., \& Chicone, S. J. (2012). Upstate Rural New York Residents' Perceptions of Climate Change. Research \& Policy Brief Series ISSUE NUMBER 50/OCTOBER 2012

UNESCO. (2010). The Role of Traditional and Local Knowledge in Climate Change Adaptation $5^{\text {th }}$ Global Conference in Oceans, Coasts and Island May 3-7 2010. Paris In Adebayo \& Oruonge (2012), An Investigation of Local Farmers Assessment of Climate Change in N/Taraba State Nigeria.

UNFCCC. (1992). Rio de Janeiro, Brazil. Retrieved from $\mathrm{http} / / \mathrm{www}$. unfccc.int/text/resources/docs/convkp/conveng.pdf

Zemankovics, M. H. (2012). Mitigation and adaptation to Climate Change in Hungary. Journal of Central European Agriculture, 13(1), 58-72. http://dx.doi.org/10.5513/JCEA01/13.1.1015

\section{Copyrights}

Copyright for this article is retained by the author(s), with first publication rights granted to the journal.

This is an open-access article distributed under the terms and conditions of the Creative Commons Attribution license (http://creativecommons.org/licenses/by/3.0/). 